\title{
Bond Repudiation, Tax Codes, the Appropriations Process and Restitution Post-Eminent Domain Reform
}

\author{
by John Ryskamp
}

The anti-eminent domain movement is notoriously heedless of the implications of the reforms it proposes. It lost the Kelo case because the Supreme Court pointed out that the movement's bugaboo - economic development — could not be distinguished logically from other eminent domain purposes. The Court's conclusion has withstood analysis.

Nothing daunted, the anti-eminent domain movement has succeeded in passing reforms which purport to do just that. Also which purport to change the definition of blight. Across the board, these changes to generalities are problematic because they do not reference facts. Houses and businesses - supposedly protected under the reformsnever seem to be mentioned in the legislation.

But reforms have been enacted into law, and we have to deal with them. What are their implications? Assuming these reforms are upheld, other areas of law need attention, areas to which the anti-eminent domain movement has given no thought. Some of the laws have even seen "success." For example, recently enacted Wisconsin eminent domain reform included a definition of blight as vague as any: "'blighted property" means any property that, by reason of abandonment, dilapidation, deterioration, age or obsolescence, inadequate provisions for ventilation, light, air, or sanitation, high density of population and overcrowding, faulty lot layout in relation to size, adequacy, accessibility, or usefulness, unsanitary or unsafe conditions, deterioration of site or other improvements, or the existence of conditions that endanger life or property by fire or other causes, or any combination of such factors, is detrimental to the public health, safety, or welfare."1 One could drive a truck through the loopholes in this definition. The point is, it works. Or seems to:

Developers of Landmark Gate announced Tuesday they were abandoning a proposed \$25 million mixed use project at [Madison, Wisconsin's] Todd Drive and the Beltline. Mortenson Investment Group [MIG] said the state law, which was passed overwhelmingly by the Legislature and signed by Gov. Jim Doyle in late March, had removed its needed leverage to acquire property for the project....[Developer Brad] Hutter...said the difficulties in acquiring properties along the Beltline-including the controversial Selective Video adult entertainment shop were crippled by the law. MIG had purchased two properties and had contracts with two others but was unable to reach agreement with owners of the Open Pantry convenience store and the Bridge Club sites. The Landmark Gate project was awarded to MIG in August 2005 after the city created a redevelopment district along Todd Drive. Hutter said his group entered into the project fully expecting the city's Community Development Authority would use its powers of eminent domain should property acquisition be financially or legally unreasonable. The project has been nearly five years in the making. It included a four-story building with 429 underground parking stalls and 184 surface stalls for retail customers. The upper three floors of the 135,000 square-foot

\footnotetext{
${ }^{1}$ The entire text of the legislation is online at www.legis.state.wi.us.
} 
building would be offices, including a new home for Madison-based NRS Corp., an independent consulting firm specializing in research for the home building industry. The bottom floor would house stores and eateries, such as a coffee shop, deli, dry cleaners and bank. ${ }^{2}$

It would be nice to say that this ends the story of Wisconsin's new law of blight.

But it is only the beginning. One unlooked-for result is to throw all past government actions into question. What rights now vest in what facts from the consideration of Wisconsin's new law? How is all finance implicated-health and welfare regulation, any kind of building, all bonds, taxes and appropriations - by this new law? Loose eminent domain reform left loose ends.

Consider the bond indebtedness incurred from past eminent domain seizures which, in the contemplation of this new definition, were wrongful. Should that indebtedness be repudiated? What about bond indebtedness resulting from duress, that is, sales pursuant to the perceived threat of eminent domain using the former law? What about indebtedness resulting from wrongful zoning under the former law? From wrongful health and welfare regulation under the former law? And which were the regulatory wrongs committed? What are the grounds on which repudiation/restitution should proceed?

Eminent domain reform is designed to preserve property. The implication is that its former wrongful use deprived others of property. In order to prevent this from ever happening again, does the new blight definition mandate controls on appropriations? Does it mandate rewriting the state's tax code?

Do these possibilities seem draconian? Then consider the following referendum to be placed on the November 2007 South Dakota ballot, in part in response to the Kelo decision:

The South Dakota Judicial Accountability Initiative Law [JAIL] is a ballot measure that would establish a process to allow litigants to sue judges for various kinds of misconduct....The proposed amendment to the state's constitution would create a special grand jury that would have the power to set aside a judge's judicial immunity and allow a petitioner to sue a judge for either civil or criminal misconduct. JAIL is intended to address a laundry list of alleged judicial abuses, including eminent domain abuse, probate fraud, falsification of court records, and family court misconduct, says Gary Zerman, a Valencia, Calif., lawyer who is both a consultant and spokesman for JAIL. The text of the amendment, posted on the Web site [www.jail4judges.org], says judges shall not have immunity for:

- Deliberate violations of the law, or of the state or federal constitutions.

- Fraud or conspiracy.

- Intentional violations of due process.

- Deliberate disregard of material facts.

- Judicial acts without jurisdiction.

${ }^{2}$ The Capitol Times, June 21, 2006 (Madison, Wisconsin, archived at www.madison.com). 
- Acts that impede the lawful conclusion of a case, including unreasonable delay and willful rendering of an unlawful judgment or order. ${ }^{3}$

If this can be done to judges, why may not something equivalent be done to outstanding debt?

${ }^{3}$ Quoted on the American Homeowners Resource Center (June 20, 2006, archived at www.ahrc.com). 